\title{
Rhodium-Prussian Blue Modified Carbon Paste Electrode (Rh-PBMCPE) for Amperometric Detection of Hydrogen Peroxide
}

\author{
Viviane Midori Ivama and Silvia H. P. Serrano* \\ Instituto de Química, Universidade de São Paulo, CP 26077, 05513-970 São Paulo - SP, Brazil
}

\begin{abstract}
Filmes de azul da Prússia foram superficialmente depositados em eletrodos de pasta de carbono a partir de soluções contendo $2,0 \times 10^{-3} \mathrm{~mol} \mathrm{~L}^{-1} \mathrm{de} \mathrm{K}_{3}\left[\mathrm{Fe}(\mathrm{CN})_{6}\right], 3,0 \times 10^{-3} \mathrm{~mol} \mathrm{~L}^{-1} \mathrm{FeCl}_{3}$ e $1,0 \mathrm{x}$ $10^{-2} \mathrm{~mol} \mathrm{~L}^{-1} \mathrm{HCl}$, usando dois potenciais controlados. Para aumentar a estabilidade do eletrodo modificado, efetuaram-se 50 ciclos em solução contendo $1,0 \times 10^{-3} \mathrm{~mol} \mathrm{~L}^{-1} \mathrm{de} \mathrm{RhCl}_{3}, 0,50 \mathrm{~mol} \mathrm{~L}^{-1} \mathrm{de}$ $\mathrm{KCl}$ e $1,0 \times 10^{-2} \mathrm{~mol} \mathrm{~L}^{-1}$ de $\mathrm{HCl}$ no intervalo de $-0,40 \mathrm{a}+0,60 \mathrm{~V}^{2} 60 \mathrm{mVs}^{-1}$. Estes eletrodos, denominados de Rh-PBMCPE, apresentaram boa estabilidade durante a determinação amperométrica de $\mathrm{H}_{2} \mathrm{O}_{2}$ a $0,040 \mathrm{~V}$ sem a interferência dos ácidos ascórbico e úrico. A corrente de redução variou linearmente com a concentração de $\mathrm{H}_{2} \mathrm{O}_{2}$ no intervalo de 5,0 x $10^{-5}$ a 8,6 x $10^{-4} \mathrm{~mol} \mathrm{~L}^{-1}$. O limite de detecção foi de $2,8 \times 10^{-5} \mathrm{~mol} \mathrm{~L}^{-1}$ com sensibilidade variando de 1,32 a $0,96 \mathrm{~A} \mathrm{~mol}^{-1} \mathrm{~L} \mathrm{~cm}^{-2}$ ao longo de cinco dias (180 determinações).
\end{abstract}

Prussian Blue was deposited at carbon paste electrode surface from a solution containing $2.0 \mathrm{x}$ $10^{-3} \mathrm{~mol} \mathrm{~L}^{-1} \mathrm{~K}_{3}\left[\mathrm{Fe}(\mathrm{CN})_{6}\right], 3.0 \times 10^{-3} \mathrm{~mol} \mathrm{~L}^{-1} \mathrm{FeCl}_{3}$ and $1.0 \times 10^{-2} \mathrm{~mol} \mathrm{~L}^{-1} \mathrm{HCl}$ using two controlled potentials. To improve the stability of the modified electrode it was 50 times cycled in a solution containing $1.0 \times 10^{-3} \mathrm{~mol} \mathrm{~L}^{-1} \mathrm{RhCl}_{3}, 0.50 \mathrm{~mol} \mathrm{~L}^{-1} \mathrm{KCl}$ and $0.010 \mathrm{~mol} \mathrm{~L}^{-1} \mathrm{HCl}$ in the potential range from $-0.40 \mathrm{~V}$ to $0.60 \mathrm{~V}$ at $60 \mathrm{mV} \mathrm{s}^{-1}$. The $\mathrm{Rh}$ - Prussian Blue carbon paste modified electrode ( $\mathrm{Rh}$ PBMCPE) showed good stability during amperometric catalytic determination of $\mathrm{H}_{2} \mathrm{O}_{2}$ at $0.040 \mathrm{~V}$, without ascorbic and uric acids interferences. The current changed linearly with $\mathrm{H}_{2} \mathrm{O}_{2}$ concentrations in the range of $5.0 \times 10^{-5}-8.6 \times 10^{-4} \mathrm{~mol} \mathrm{~L}^{-1}$. The estimated detection limit was $2.8 \times 10^{-5} \mathrm{~mol} \mathrm{~L}^{-1}$ with sensibility changing from 1.32 to $0.96 \mathrm{~A} \mathrm{~mol}^{-1} \mathrm{~L} \mathrm{~cm}^{-2}$ along five days (180 determinations).

Keywords: prussian blue, rhodium, carbon paste electrode, hydrogen peroxide, amperometry

\section{Introduction}

Prussian Blue modified electrodes (PBME) have been prepared by electrochemical techniques on electrodes such as glassy carbon, ${ }^{1-18}$ platinum, ${ }^{1,3,19,20-23}$ tin oxide, ${ }^{1,3,24-26}$ gold, ${ }^{3}$ graphite, ${ }^{27-28}$ titanium-silver-gold arrays, ${ }^{29}$ basal pyrolytic graphite, ${ }^{30}$ screen printed carbon ink interdigital arrays,${ }^{20}$ conducting polymer coated microelectrode arrays, ${ }^{31}$ carbon fiber, ${ }^{32}$ carbon paste, ${ }^{33}$ etc.

They were used to design new glucose, ${ }^{8-10,17,21,23,28,30,32}$ alanine,$^{30}$ alcohol ${ }^{30}$ and glutamate ${ }^{13,14}$ biosensors based on the electrochemical detection of hydrogen peroxide, which is formed in the course of the substrate enzyme-catalyzed oxidation. In these cases Nafion, ${ }^{8,10,14,17,30}$ poly (ophenylenediamine) ${ }^{21}$ polypyrrole/poly (o-phenylenediamine $)^{23}$ and poly (o-diaminebenzene $)^{18}$ polymers

\footnotetext{
*e-mail: shps@iq.usp.br
}

have been used to immobilize the enzyme and eliminate interferences from ascorbic and uric acids.

Chemical preparations were also described and involve the immersion of the working electrode in aqueous modifier solution, ${ }^{5,6,19}$ the mixture of Prussian Blue (chemically synthesized) with graphite and paraffin ${ }^{34}$ or hydrocarbons ${ }^{33}$ to produce modified carbon paste electrodes and the dispersion of Prussian Blue, supported on graphite, into methyltrimethoxysilane-derived gels to get a renewable three-dimensional modified electrode. ${ }^{35}$

PB can be reduced to Prussian White (Everitt salt) around $0.2 \mathrm{~V}$ or oxidized to Berlin Green around $0.9 \mathrm{~V}$. Generally, the films are not stable during successive cycles around of the two reversible couples of PB, but the effect is more pronounced at $0.9 \mathrm{~V},{ }^{6,25}$ perhaps because $\mathrm{Fe}^{3+}$ ions are lost to the solution during this process. ${ }^{24} \mathrm{~PB}$ films are easily destroyed during the catalytic reduction of hydrogen peroxide due to formation of $\mathrm{OH}^{-}$ions, which are able to disrupt the $\mathrm{Fe}-\mathrm{CN}$ bound in $\mathrm{PB},{ }^{12,13,17,30}$ so buffering 
capacity is an important parameter to be controlled in the applications of these modified electrodes. Nafion has been also used to improve the stability, reproducibility and sensitivity in several analytical applications. ${ }^{5,6,11}$

The activity of PBMEs for the electroreduction of molecular oxygen should be lower but it seems to be dependent on the electrode material, applied potential ${ }^{28}$ and experimental conditions in which the films are prepared. $^{4,10,13-15}$

In this paper we describe the electrodeposition of Prussian Blue on Carbon Paste Electrodes by using two different applied potentials. First, at $0.4 \mathrm{~V}$ the reagents were pre concentrated on the surface electrode. ${ }^{36}$ Subsequently, the applied potential was reversed to $-0.4 \mathrm{~V}$ and PB, probably the "insoluble form", was deposited on the electrode surface. The modification process was repeated twice. To improve the stability of the modified electrode it was cycled in a solution containing $0.1 \mathrm{~mol} \mathrm{~L}^{-1}$ $\mathrm{KCl}, 1.0 \times 10^{-3} \mathrm{~mol} \mathrm{~L}^{-1} \mathrm{RhCl}_{3}$ and $0.02 \mathrm{~mol} \mathrm{~L}^{-1} \mathrm{HCl}$ in the potential range from $-0.4 \mathrm{~V}$ to $+0.6 \mathrm{~V}$ at $60 \mathrm{mVs}^{-1}$. The modified electrode was dried in ambient temperature during $24 \mathrm{~h}$ before use.

Using this modification process it was possible to obtain a PB modified carbon paste electrode (Rh-PBMCPE) with good stability, reproducibility and sensitivity. Additionally, the interference from oxygen reduction or ascorbic and uric acids was avoided.

\section{Experimental}

\section{Chemicals and solutions}

All analytical reagents were from analytical grade and obtained from Merck (Rio de Janeiro, Brazil). Aldrich Chemical Co. supplied Nujol oil and $\mathrm{RhCl}_{3}$ and graphite was Acheson 38 from Fisher. All reagents were used without previous purification. Citrate/ Citric Acid buffer solutions, pH 6.1 were prepared as described previously. ${ }^{37}$ Purified water from a Barnstead Nanopure system was always used.

\section{Apparatus and electrodes}

All electrochemical measurements were performed using a potentiostat/galvanostat MQPG-01 (Santa Catarina, Brazil). pH measurements were carried out using a $\mathrm{pH}$ meter model 654 with a combined glass electrode, both from Metrohm.

The working electrode was a carbon paste, $\mathrm{A}=0.080$ $\mathrm{cm}^{2}$, prepared with graphite/Nujol in $2: 1(\mathrm{~m} / \mathrm{m})$ proportion; counter and reference electrodes were $\mathrm{Pt}$ wire and a miniaturized $\mathrm{Ag} / \mathrm{AgCl}$ (saturated $\mathrm{KCl}$ ) electrode, ${ }^{38}$ respectively all contained in a one-compartment cell.

Rh-PB-Modified Carbon Paste (Rh-PBMCP), PB-Modified Carbon Paste (PB-MCP) and Rh-Modified Carbon Paste (Rh-MCP) Electrodes

Rh-PBMCP electrodes : carbon paste electrodes were immersed in a stirred solution containing $2.0 \times 10^{-3} \mathrm{~mol} \mathrm{~L}^{-1}$ $\mathrm{K}_{3}\left[\mathrm{Fe}(\mathrm{CN})_{6}\right], 3.0 \times 10^{-3} \mathrm{~mol} \mathrm{~L}^{-1} \mathrm{FeCl}_{3}$ and $1.0 \times 10^{-2} \mathrm{~mol} \mathrm{~L}^{-1}$ $\mathrm{HCl}$. The working electrode was maintained at $0.4 \mathrm{~V}$ during $2 \mathrm{~min}$ (pre concentration step) ${ }^{35}$ and just reversed to $-0.4 \mathrm{~V}$, also during $2 \mathrm{~min}$ (step during which the "insoluble" Prussian Blue was precipitated on the electrode surface). This process was repeated twice. After that the electrodes were washed with deionised water and transferred to an electrochemical cell containing $1.0 \times 10^{-3} \mathrm{~mol} \mathrm{~L}^{-1} \mathrm{RhCl}_{3}, 0.50 \mathrm{~mol} \mathrm{~L}^{-1} \mathrm{KCl}$ and $0.010 \mathrm{~mol} \mathrm{~L}^{-1} \mathrm{HCl}$ and 50 cyclic voltammograms were recorded at $60 \mathrm{mV} \mathrm{s}^{-1}$ in the range of -0.4 to $+0.6 \mathrm{~V}$. The working electrode was dried at room temperature overnight before use. PB-MCP and Rh-MCP electrodes were prepared using the same process but without treatment in $\mathrm{RhCl}_{3}$ solution (PB-MCP electrode) or using only $1.0 \times 10^{-3} \mathrm{~mol} \mathrm{~L}^{-1}$ $\mathrm{RhCl}_{3}, 0.50 \mathrm{~mol} \mathrm{~L}^{-1} \mathrm{KCl}$ and $0.010 \mathrm{~mol} \mathrm{~L}^{-1} \mathrm{HCl}$ as a modifying solution (Rh-MCP electrode).

\section{Amperometric hydrogen peroxide detections}

The Rh-PBMCPE, reference and counter electrodes were immersed in the electrochemical cell containing $10.00 \mathrm{~mL}$ of citric acid/potassium citrate buffer at $\mathrm{pH} 6.1$ in $0.5 \mathrm{~mol} \mathrm{~L}^{-1} \mathrm{KCl}$ solution. Measurements were performed at $0.040 \mathrm{~V}$ after several additions of $5.0 \times 10^{-3} \mathrm{~mol} \mathrm{~L}^{-1}$ $\mathrm{H}_{2} \mathrm{O}_{2}$. After each $\mathrm{H}_{2} \mathrm{O}_{2}$ addition, current values were subtracted from background current (recorded in supporting electrolyte), to get the analytical curves.

\section{Rh-PB-Modified Carbon Paste Electrode (Rh-PBMCPE) behaviour in ascorbic and uric acid solutions}

The Rh-PBCPME, reference and counter electrodes were immersed in the electrochemical cell containing $10.00 \mathrm{~mL}$ of citric acid/potassium citrate buffer at $\mathrm{pH} 6.1$ in $0.5 \mathrm{~mol} \mathrm{~L}^{-1} \mathrm{KCl}$ solution. After stabilization of the baseline, an aliquot of $100 \mu \mathrm{L}$ of $1.0 \times 10^{-1} \mathrm{~mol} \mathrm{~L}^{-1}$ ascorbic or uric acids was injected in the cell and current values recorded in the range of -0.21 to $+0.19 \mathrm{~V}$.

\section{Results and Discussion}

Figure 1 shows the $1^{\text {st }}, 30^{\text {th }}$ and $50^{\text {th }}$ cyclic voltammo- 
gramms carried out in a solution containing $1.0 \times 10^{-3} \mathrm{~mol} \mathrm{~L}^{-1}$ $\mathrm{RhCl}_{3}, 0.5 \mathrm{~mol} \mathrm{~L}^{-1} \mathrm{KCl}$ and $0.01 \mathrm{~mol} \mathrm{~L}^{-1} \mathrm{HCl}$. The $\mathrm{Rh}-$ PBCPME shows good stability during successive cycles, with anodic and cathodic peaks recorded at $0.30 \mathrm{~V}$ and $0.18 \mathrm{~V}$ being attributed to a redox process involving Prussian White/Prussian Blue couple. $\mathrm{E}^{0}$ calculated as $\left(\mathrm{E}_{\mathrm{p}, \mathrm{a}}+\mathrm{E}_{\mathrm{p}, \mathrm{c} / 2}\right)$, is $0.24 \mathrm{~V}$.

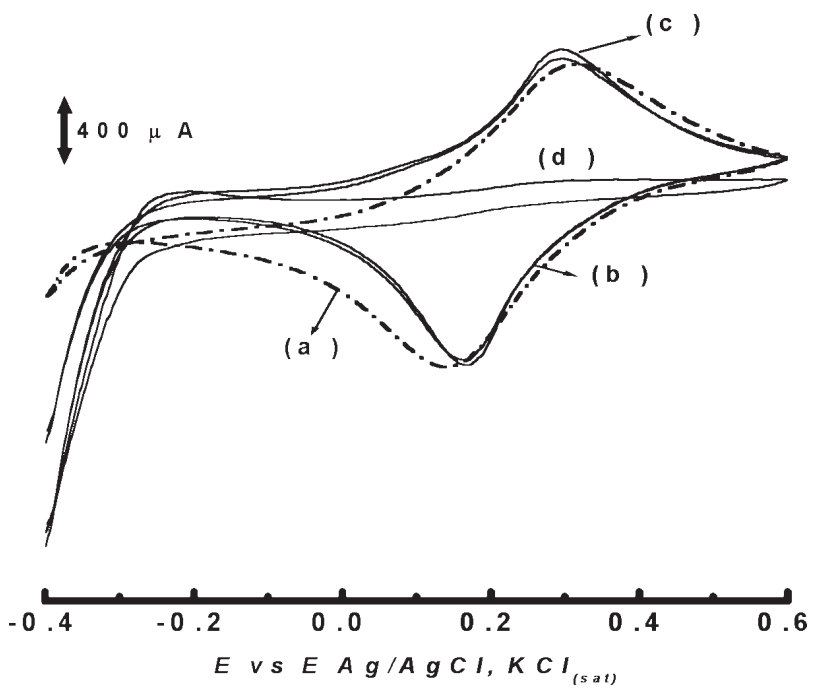

Figure 1. (a) $1^{\text {st }}$, (b) $30^{\text {th }}$ and (c) $50^{\text {th }}$ cyclic voltammograms carried out with a PB - carbon paste modified electrode (PB-CPME) and (d) with unmodified carbon paste electrode in a solution containing $1.0 \mathrm{x}$ $10^{-3} \mathrm{~mol} \mathrm{~L}^{-1} \mathrm{RhCl}_{3}, 0.5 \mathrm{~mol} \mathrm{~L}^{-1} \mathrm{KCl}$ and $0.01 \mathrm{~mol} \mathrm{~L}^{-1} \mathrm{HCl}$ at $60 \mathrm{mVs}^{-1}$.

In potassium citrate/ citric acid buffer solution containing $0.5 \mathrm{~mol} \mathrm{~L}^{-1} \mathrm{KCl}$ at $\mathrm{pH} 6.1$, the peak currents changed linearly with the square of sweep rate in the range from 0.025 to $0.400 \mathrm{Vs}^{-1}$ showing that the process is governed by ion diffusion from support electrolyte to the electrode surface (during the reduction step) or from the electrode to the solution (during the oxidation step) to ensure the electroneutrality rule.

The modifier surface excess was $4.3 \times 10^{-8} \mathrm{~mol} \mathrm{~cm}^{-2}$, calculated using the anodic charge obtained from cyclic voltammograms, after subtraction of the background charge recorded with an unmodified carbon paste electrode in an electrolyte support solution $\left(1.0 \times 10^{-3} \mathrm{~mol} \mathrm{~L}^{-1} \mathrm{RhCl}_{3}\right.$, $0.5 \mathrm{~mol} \mathrm{~L}^{-1} \mathrm{KCl}$ and $0.01 \mathrm{~mol} \mathrm{~L}^{-1} \mathrm{HCl}, v=60 \mathrm{mV} \mathrm{s}^{-1}$ ), utilizing the relation: $\Gamma=\int(\mathrm{idt} / \mathrm{nFA})=\mathrm{Q} / \mathrm{nFA}$, where $\mathrm{Q}$ is the charge in coulombs and $A$ the electrode area in $\mathrm{cm}^{2}$. The calculated value is higher than others reported in the literature. . $9,10,12,13,16,34,35$ This was expected, since we used a pre-concentration step and higher deposition times, a total of 6 min during 3 deposition steps.

From Figure 1 it is also possible to see that no peaks were recorded, with an unmodified carbon paste electrode, in the same potential range from $-0.4 \mathrm{~V}$ to $+0.6 \mathrm{~V}$. It is possible that rhodium (III) can form binuclear species $\left(\mathrm{Rh}_{2} \mathrm{O}_{6}{ }^{3+}\right)$ inside the $\mathrm{PB}$ zeolytic structure through cyano and oxo bonds such as $\mathrm{Fe}-\mathrm{CN}-\mathrm{Rh}$ and $\mathrm{Fe}-\mathrm{O}-\mathrm{Rh}$, as previously reported ${ }^{39-43}$ using ruthenium salts. Electrocatalytic oxidation of $\mathrm{S}_{2} \mathrm{O}_{3}{ }^{2-}, 2$ - furaldehyde, cystein and As (III) using Ruthenium-Modified indium-hexacyanoferrate have been described. ${ }^{40}$

Improvement in the stability and selectivity can be attributed to Prussian Blue/Rhodium modification since the amperometric signal due catalytic reduction of $\mathrm{H}_{2} \mathrm{O}_{2}$ is lower at Prussian Blue (PB-MCPE) or Rhodium carbon paste (Rh-MCPE) modified electrodes (Figure 2).

Figure 3 shows the analytical curves obtained during hydrogen peroxide detections along 5 days. Each one of them represents an average of 6 consecutive amperometric

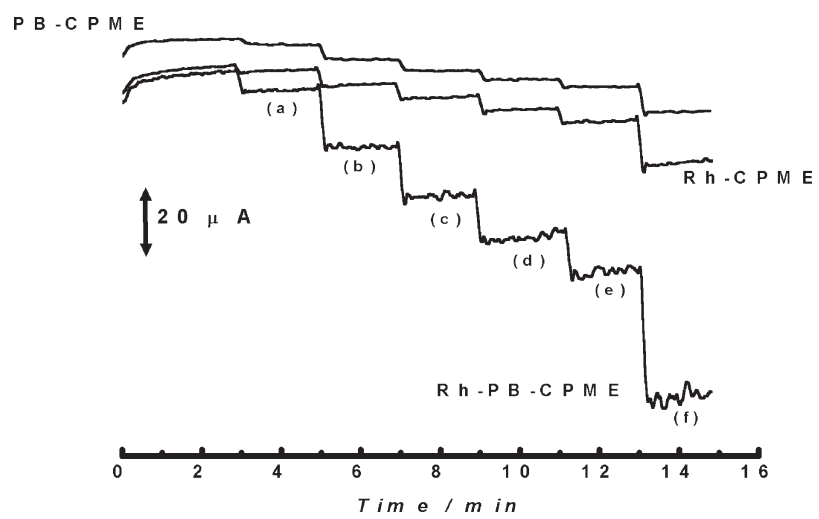

Figure 2. Amperograms recorded during the catalytic reduction of: (a) $5.0 \times 10^{-6}$, (b) $1.4 \times 10^{-4}$, (c) $2.3 \times 10^{-4}$, (d) $3.2 \times 10^{-4}$, (e) $4.0 \times 10^{-4}$ and (f) $8.6 \times 10^{-4} \mathrm{~mol} \mathrm{~L}^{-1}$ hydrogen peroxide. Applied potential = $0.040 \mathrm{~V}$ vs $\mathrm{Ag} / \mathrm{AgCl}$. Supporting electrolyte = citric acid / sodium citrate buffer solution ( $\mathrm{pH}$ 6.1) in $0.5 \mathrm{~mol} \mathrm{~L}^{-1} \mathrm{KCl}$.

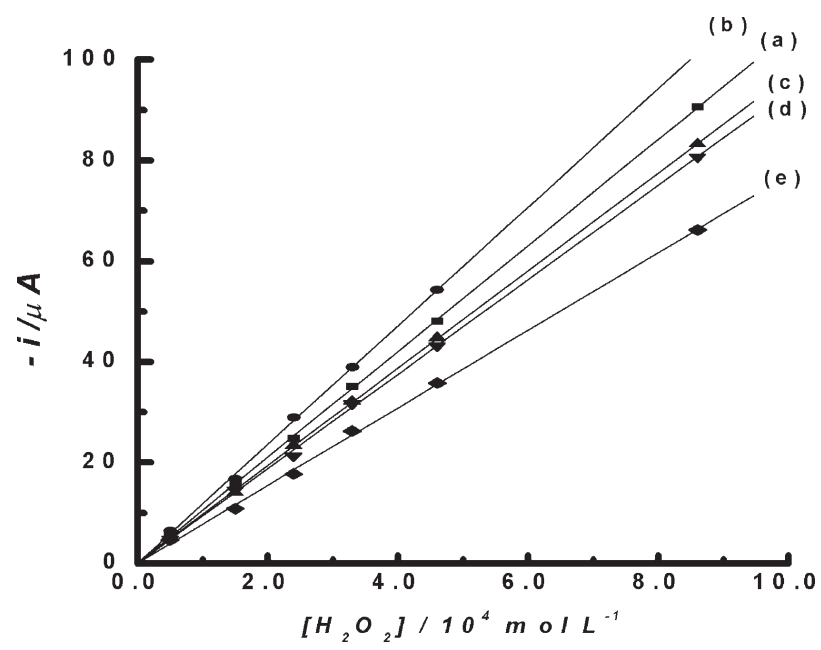

Figure 3. Analytical curves obtained for amperometric hydrogen peroxide detections with an Rh-PBCPE at $0.040 \mathrm{~V}$ : (a) $1^{\text {st }}$, (b) $2^{\text {nd }}$, (c) $3^{\text {rd }}$, (d) $4^{\text {th }}$ and (e) $5^{\text {th }}$ days. Each analytical curve represents an average of 6 consecutive amperometric analytical curves performed in the same day. 
Table 1. Principal parameters obtained from analytical curves

\begin{tabular}{llccc}
\hline Day & Equation & $\begin{array}{c}\text { Linear Range } \\
10^{4} \mathrm{~mol} \mathrm{~L}^{-1}\end{array}$ & $\begin{array}{c}\text { Sensitivity } \\
\mathrm{A} \mathrm{mol}{ }^{-1} \mathrm{~L} \mathrm{~cm}{ }^{-2}\end{array}$ & $\begin{array}{c}\text { Relative sensitivity } \\
\%\end{array}$ \\
\hline $1^{\text {st }}$ & $\mathrm{I}=0.0029+10.5\left[\mathrm{H}_{2} \mathrm{O}_{2}\right]$ & $0.5-8.6$ & $1.32 \pm 0.02$ & 100 \\
$2^{\text {nd }}$ & $\mathrm{I}=0.044+11.8\left[\mathrm{H}_{2} \mathrm{O}_{2}\right]$ & $0.5-8.6$ & $1.47 \pm 0.03$ & 111 \\
$3^{\text {rd }}$ & $\mathrm{I}=0.026+9.68\left[\mathrm{H}_{2} \mathrm{O}_{2}\right]$ & $0.5-8.6$ & $1.17 \pm 0.02$ & 92 \\
$4^{\text {th }}$ & $\mathrm{I}=0.011+9.38\left[\mathrm{H}_{2} \mathrm{O}_{2}\right]$ & $0.5-8.6$ & $0.96 \pm 0.02$ & 89 \\
$5^{\text {th }}$ & $\mathrm{I}=0.027+7.70\left[\mathrm{H}_{2} \mathrm{O}_{2}\right]$ & $0.5-8.6$ & 73 \\
\hline
\end{tabular}

analytical curves carried out in the same day. The current changed linearly with hydrogen peroxide concentrations in the range from $5.010^{-5}$ to $8.610^{-4} \mathrm{~mol} \mathrm{~L}^{-1}$; the parameters, derived from analytical curves, are presented in Table 1. The estimated detection limit $\left(2.8 \times 10^{-5} \mathrm{~mol} \mathrm{~L}^{-1}\right),{ }^{44}$ was higher than those reported in the literature for the determination of glutamate ${ }^{14}$ or direct flow injection analysis of $\mathrm{H}_{2} \mathrm{O}_{2}{ }^{15}$ and glucose $\mathrm{e}^{8,9,13}$ but the sensibility, measured during five days, changed from 1.32 to $0.96 \mathrm{~A} \mathrm{~mol}^{-1} \mathrm{~L} \mathrm{~cm}^{-2}$ and was better than values obtained with sensors covered ${ }^{8,9,14}$ or not ${ }^{13,15}$ with Nafion film, always used to protect the modified electrode surface and to immobilize the enzyme. ${ }^{8,9}$ After 5 days, the Rh-PBMCP electrode still maintained $73 \%$ of its activity for catalytic reduction of hydrogen peroxide (Table 1).

Figure 4 shows that at $0.040 \mathrm{~V}$ about $8 \%$ of the total current recorded in $1.0 \times 10^{-3} \mathrm{~mol} \mathrm{~L}^{-1} \mathrm{H}_{2} \mathrm{O}_{2}$ solution corresponds to direct $\mathrm{O}_{2}$ reduction (Figure 4a) and no interference was detected due to mediated or direct oxidation of uric acid (Figure 4b). Interference of ascorbic acid was significant only at $0.060 \mathrm{~V}$ or higher applied potentials (Figure 4c).

\section{Conclusions}

In the present study an alternative procedure to prepare Prussian Blue carbon paste modified electrodes was described. Using two distinct steps, reagent preconcentration and Prussian Blue deposition, followed by rhodium incorporation in the PB zeolytic strucuture, it was possible to design modified electrodes with good stability and reproducibility in the catalytic reduction of hydrogen peroxide. These results, associated to those reported before by other researchers represent a continuous effort in optimising Prussian Blue modified electrodes for electroanalytical applications.

\section{Acknowledgements}

Viviane Midori Ivama thanks CNPq for a fellowship; we thank FAPESP (Processo 01/011923and CNPq for financial support and Dr. Paulo Celso Isolani for helpful suggestions. (a)

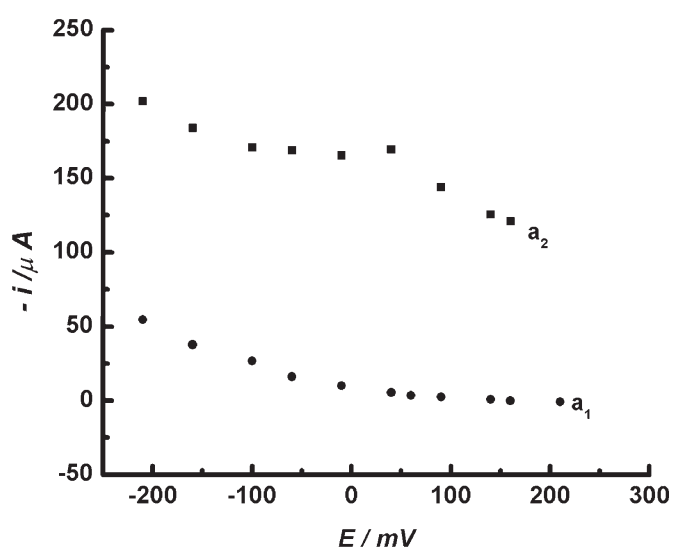

(b)

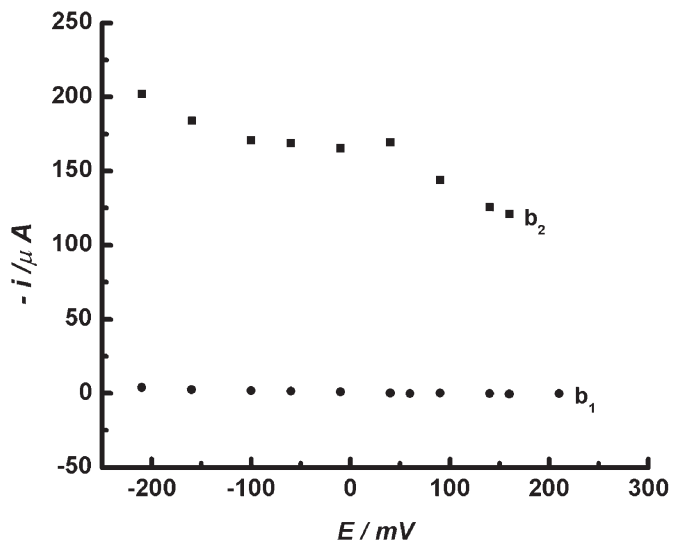

(c)

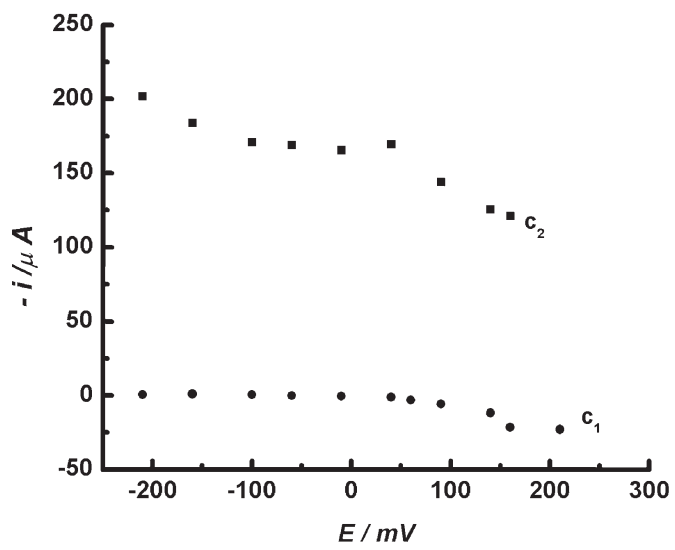

Figure 4. Rh-PBCPE amperometric currents recorded in citric acid/ sodium citrate, $\mathrm{pH} 6.1$, containing $0.5 \mathrm{~mol} \mathrm{~L}^{-1} \mathrm{KCl}$ in the presence of $\mathrm{O}_{2}\left(\mathrm{a}_{1}\right)$, absence of $\mathrm{O}_{2}$ and $1.0 \times 10^{-3} \mathrm{~mol} \mathrm{~L}^{-1} \mathrm{H}_{2} \mathrm{O}_{2}\left(\mathrm{a}_{2}\right)$; absence of $\mathrm{O}_{2}$ and $1.0 \times 10^{-3} \mathrm{~mol} \mathrm{~L}^{-1}$ uric acid $\left(\mathrm{b}_{1}\right)$ and absence of $\mathrm{O}_{2}$ and $1.0 \times 10^{-3}$ mol L-1 $\mathrm{H}_{2} \mathrm{O}_{2}\left(\mathrm{~b}_{2}\right)$; absence of $\mathrm{O}_{2}$ and $1.0 \times 10^{-3} \mathrm{~mol} \mathrm{~L}^{-1}$ ascorbic acid $\left(c_{1}\right)$ and absence of $\mathrm{O}_{2}$ and $1.0 \times 10^{-3} \mathrm{~mol} \mathrm{~L}^{-1} \mathrm{H}_{2} \mathrm{O}_{2}\left(\mathrm{c}_{2}\right)$. 


\section{References}

1. Itaya, K.; Akahoshi, H.; Toshima, S.; J. Electrochem. Soc. 1982, 129,1498 .

2. Itaya, K.; Ataka, T.; Toshima, S.; Shinohara, T.; J. Phys. Chem. 1982, 86, 2415.

3. Itaya, K.; Ataka, T.; Toshima, S.; J. Am. Chem. Soc. 1982, 104, 4767.

4. Itaya, K.; Shoji, N.; Uchida, I.; J. Am. Chem. Soc. 1984, 106, 3423.

5. Hou, W.; Wang, E.; J. Electroanal. Chem. 1991, 316, 155.

6. Hou, W.; Wang, E.; Anal. Chim. Acta 1992, 257, 275.

7. Zhou, J.; Wang, E.; J. Electroanal. Chem. 1992, 331, 1029.

8. Karyakin, A. A.; Gitelmacher, O. V.; Karyakina, E. E.; Anal. Lett. 1994, 27, 2861.

9. Karyakin, A. A.; Gitelmacher, O. V.; Karyakina, E. E.; Anal. Chem. 1995, 67, 2419.

10. Karyakin, A. A.; Karyakina, E. E.; Gorton, L.; Talanta 1996, 43, 1597.

11. Lu, W.; Walace, G. G.; Karyakin, A. A.; Electroanal. 1998, 10, 472.

12. Karyakin, A. A.; Karyakina, E. E.; Gorton, L.; Electrochem. Commun. 1999, 1, 78.

13. Karyakin, A. A.; Karyakina, E. E.; Sensors Actuactors B. 1999 , 57, 268.

14. Karyakin, A. A.; Karyakina, E. E.; Gorton, L.; Anal. Chem. 2000, 72, 1720

15. de Mattos, I. L.; Gorton, L.; Ruzgas, T.; Karyakin, A. A.; Anal. Sci. 2000, 16, 795.

16. Castro, S. S. L.; Balbo, V. R.; Barbeira, P. J. S.; Stradiotto, N. R.; Talanta, 2001, 55, 249.

17. de Mattos, I. L.; Lukachova, L. V.; Gorton, L.; Laurell, T.; Karyakin, A. A.; Talanta 2001, 54, 963.

18. Lukachova, L. V.; Kotel’nikova, E. A.; D’Ottavi, D.; Shkerin,. E. A.; Karyakina, E. E.; Moscone, D.; Palleschi, G.; Curulli, A.; Karyakin, A. A; Bioelectrochemistry 2002, 55, 145.

19. Lundgren, C. A.; Murray, R. W.; Inorg. Chem. 1988, $27,933$.

20. McCormac, T.; Cassidy, J.; Cameron, D.; Electroanal. 1996, 8, 195.

21. Garjonyte,R.; Malinauskas A.; Sensors Actuators B 1999, 56, 85.

22. Oliveira, M. F.; Mortimer, R. J.; Stradiotto, N. R.; Microchem. J. 2000, 64, 155.
23. Garjonyte, R.; Malinauskas, A.; Sensors Actuactors B 2000, 63, 122.

24. Plichon, V.; Besbes, S.; J. Electroanal. Chem. 1990, 284, 141.

25. García - Jareño, J.J.; . Sanmatías, A.; Vicente F.; Gabrielli, C.; Keddam, M.; Perrot, H.; Electrochim. Acta 2000, 45, 3765.

26. Ho, K. - C.; Lin, C. - L.; Sensors Actuactors B 2001, 76, 512.

27. Neff, V. D.; J. Electrochem. Soc. 1985, 132, 1382.

28. Deng, Q.; Lin, B.; Dong, S.; Analyst 1998, 123, 1995.

29. Hartmann, M.; E. W. Grabner; Anal. Chim. Acta 1991, 242, 249.

30. Chi, Q.; Dong, S.; Anal. Chim. Acta 1995, 310, 429.

31. Lu, W.; Nguyen, T.; Wallace, G. G.; Electroanal. 1998, 10, 1101.

32. Zhang, X.; Wang, J.; Ogorevc, B.; Spichiger, U. E.; Electroanal. 1999, 11, 945.

33. Garjonyte, R.; Malinauskas, A.; Sensors Actuactors B 1998, 46, 236.

34. Khlert, H.; Komorsky-Lovriæ, S.; Hermes, M.; Scholz F.; Fresenius J. Anal. Chem. 1996, 356, 204.

35. Wang, P.; Yuan, Y.; Wang, X.; Zhou, G.; J. Electroanal. Chem. 2000, 493, 130.

36. Pharr, C. M.; Griffiths, P.R.; Anal. Chem. 1997, 69, 4673.

37. Perrin, D.D.; Dempsey, B.; Buffer for pH and Metal Ion Control; Science Paperback, Chapman and Hall: London, 1983.

38. Pedrotti, J.J.; Angnes, L.; Gutz, I. G. R.; Electroanal. 1996, 8, 673.

39. Cataldi, T. R. I.; Benedetto, G. E.; Campa, C.; J. Electroanal. Chem. 1997, 437, 93.

40. Cataldi, T. R. I.; Benedetto, G. E.; Bianchini, A.; Electroanal. 1998, 10, 1163.

41. Cataldi, T. R. I.; Benedetto, G. E.; J. Electroanal. Chem. 1998, 458,149

42. Benedetto, G. E.; Cataldi, T. R. I.; Langmuir 1998, 14, 6274.

43. Benedetto, G. E.; Guascito, M. R.; Ciriello, R.; Cataldi, T. R. I.; Anal. Chim. Acta 2000, 410, 143.

44. Miller, J. C.; Miller, J. N.; Statistics for Analytical Chemistry, $2^{\text {nd }}$ ed.; Ellis Horwood: London, 1988, chap. 5.

Received: December 4, 2002

Published on the web: July 16, 2003

FAPESP helped in meeting the publication costs of this article. 